\title{
Treatment of varicose ulcer of the lower limbs by surgery and Unna boot: savings for the Brazilian healthcare system
}

\author{
Tratamento da úlcera varicosa dos membros inferiores mediante cirurgia e bota de Unna: \\ uma economia para o sistema de saúde brasileiro
}

\author{
Sergio Quilici Belczak ${ }^{1}$, Vitor Cervantes Gornati², Ricardo Aun ${ }^{1}$, Igor Rafael Sincos ${ }^{1}$, Hélio Fragoso ${ }^{3}$
}

\begin{abstract}
Objective: To perform an analysis of the costs of treatment of varicose ulcers by radical surgery of varices and the use of Unna boot. Methods: Fifteen outpatients were selected to receive treatment of varicose ulcers with radical surgery and Unna boot. The total cost of treatment was calculated (hospitalization, surgery, dressings, and outpatient's follow-up visits) and compared to the cost of clinical follow-up with daily simple dressing changes. Results: The proposed treatment was on average $55.71 \%$ more economical than the management with daily dressings (approximately US $\$ 452.32$ versus US $\$ 1,021.39$ ). Conclusion: Radical varicose vein surgery associated with the use of the Unna boot proved meaningly less expensive for the public health system than clinical follow-up with daily dressings.
\end{abstract}

Keywords: Varicose ulcer/surgery; Varicose ulcer/economics; Public health

\section{RESUMO}

Objetivo: Realizar uma análise de custo do tratamento da úlcera varicosa mediante cirurgia radical de varizes e uso de bota de Unna. Métodos: quinze pacientes foram selecionados ambulatorialmente para receber 0 tratamento da úlcera varicosa com cirurgia radical de varizes e bota de Unna, sendo o custo total do tratamento contabilizado (internação, cirurgia, curativos e retornos ambulatoriais) e comparado ao custo do acompanhamento clínico com curativos simples trocados diariamente. Resultados: 0 tratamento proposto foi em média $55,71 \%$ mais econômico que o manejo com curativos diários $(\mathrm{R} \$ 717,84 \times \mathrm{R} \$$ $1.620,95$ ou aproximadamente US $\$ 452.32$ x US $\$ 1,021.39$ ). Conclusão: 0 emprego da cirurgia radical de varizes associado ao uso de bota de Unna provou-se expressivamente menos dispendioso para a saúde pública do que o acompanhamento clínico com curativos diários.

Descritores: Úlcera varicosa/cirurgia; Úlcera varicosa/economia; Saúde pública

\section{INTRODUCTION}

The varicose ulcer (VU) is one of the most severe manifestations of chronic venous insufficiency (CVI) of the lower limbs, a disease of great importance to public health due to its high incidence and prevalence and because of the high socioeconomic impact that it brings, since it is difficult to treat and requires prolonged work absenteeism. This morbidity frequently presents associated with varices and trophic lesions of the lower limbs.

CVI may be classified as a syndrome that includes from telangiectasias to active ulcers, originating in chronic venous hypertension caused by venous obstruction or reflux, with or without muscle pump insufficiency ${ }^{(1)}$.

In Western countries, CVI affects 15 to $50 \%$ of the adult population ${ }^{(2-4)}$, and of these, 15 to $20 \%$ present with venous stasis ulcers ${ }^{(2,3)}$. The incidence of CVI and VU in the United States was 7.61/10000 persons-year and 1.8/10000 persons-year, respectively, during the period between 1966 and 1990, with a tendency towards stabilization $^{(4)}$, totaling up, respectively, 7 million and one million people in the United States ${ }^{(3)}$. Some European studies demonstrated that approximately 1 to $2 \%$ of the population is affected ${ }^{(5-7)}$, while in Brazil it is estimated that $3.6 \%$ of the population presents with active or healed VU $(2.3 \% \text { in men and } 4 \% \text { in women })^{(8)}$.

Venous ulcerations of the lower limbs represent an important portion of public expenditure with healthcare, accounting for $1 \%$ of all costs with public health in developed countries ${ }^{(9)}$. It is estimated that the absolute cost of care for a patient with VU is about US $\$ 40,000$

\footnotetext{
Study carried out at Hospital Geral de Carapicuíba - Carapicuíba (SP), Brazil.

Hospital Israelita Albert Einstein - HIAE, Sao Paulo (SP), Brazil.

${ }^{2}$ General Surgery Residency Program, Hospital das Clínicas, Faculdade de Medicina, Universidade de São Paulo - USP, Sao Paulo (SP), Brazil.

${ }^{3}$ Department of General Surgery, Hospital Geral de Carapicuíba - Carapicuíba (SP), Brazil.

Corresponding author: Sergio Quilici Belczak - Avenida Albert Einstein, 627 - Morumbi - CEP 05651-901 - São Paulo (SP), Brazil - Tel.: 112151 -1233 - E-mail: belczak@gmail.com

Receive on: Feb 9, 2011 - Accepted on: May 15, 2011

Conflict of interest: none
} 
tallying annual costs of around US $\$ 3$ billion in the United States $^{(2)}$ and of $£ 400$ to $£ 600$ million in the United Kingdom $^{(10-12)}$, where $£ 100$ million are spent on dressings alone ${ }^{(13)}$, which exposes the fact that dressing and nursing services are the primary components of these figures ${ }^{(14)}$. These figures are even greater when one refers to longterm ulcers ( $>6$ months), larger ulcers $\left(>10 \mathrm{~cm}^{2}\right)$, and ulcers with complications, such as deep skin infections, osteomyelitis, and amputations ${ }^{(15)}$.

In Brazil, the prevalence of CVI is estimated at $47.6 \%{ }^{(8)}$, and represents the $14^{\text {th }}$ cause of work absenteeism $^{(16)}$ and a frequent cause of hospitalization - in 2009, there were 84,000 admissions to public and associated hospitals, which generated costs of approximately $\mathrm{R} \$ 48$ million to the Brazilian Unified Healthcare System (SUS) ${ }^{(17)}$, not including outpatient's care and dressings. During the year 2000, 13 thousand hospitalizations were due to open ulcers ${ }^{(17)}$.

Despite being more common in elderly persons, with a peak of prevalence in individuals aged between 60 and 80 years $^{(18,19)}, 22 \%$ of those affected are approximately 40 years of age, while $13 \%$ develop VU before they reach 30 years of age ${ }^{(10,20)}$, evidencing the losses that this disease causes in work production.

Of all lower limb ulcers, approximately 70 to $80 \%$ are caused by $\mathrm{CVI}^{(21-23)}$. The first venous stasis ulcer episode occurs, in average, five years after the diagnosis of $\mathrm{CVI}^{(3)}$ and, in patients with $\mathrm{VU}, 47 \%$ have already had two or more ulceration episodes, whereas $21 \%$ of them have already had six or more episodes ${ }^{(23)}$. The annual recurrence rate varies from 33 to $42 \%{ }^{(24,25)}$.

In general, $60 \%$ of the ulcers remain for a period of 6 months or longer ${ }^{(26)}$, and over $40 \%$ of them persist for more than one year ${ }^{(27,28)}$. The mean duration is 6 to 9 months, varying from 4 weeks to 72 years ${ }^{(29)}$.

There are multiple forms proposed for the treatment of VU, from simple elevation of the affected limb to surgery, including grafts and various types of dressings. Elevation of the limb is simple and accelerates healing of the ulcer, but cannot be performed isolatedly nor continually in patients who are not bedridden. Skin grafts have strict indications and can only be performed in specialized centers, in which surgery of the superficial system is less costly and easier to carry out, with a good cure rate and decreased recurrence rate ${ }^{(21)}$, but it is only indicated in patients with a predominance of superficial venous system insufficiency. Compressive dressings produce good results and have low costs, but they do not interfere in recurrence, considering that the causal factor was not removed.

Developed countries have invested large sums in research to develop new types of dressings ${ }^{(14)}$, such as those impregnated with silver, those impregnated with honey, and those with larval therapy. These have high costs and have not demonstrated better results than traditional compressive dressings, such as the Unna boot ${ }^{(14,30,31)}$. This is made of gauze impregnated with glycerin, gelatin, and zinc oxide, and there is no justification, therefore, for the use of expensive products that do not promote better cure rates than the usual less expensive $^{(14)}$ and equally effective dressings.

Thus, it may be observed that the high morbidity of VU fully ratifies the search for a method of treatment that has greater/better cost-effectiveness, aiming not only to decrease the patients' suffering and the number of days away from habitual activities, but the high costs to public coffers as well. The treatment of VU by means of the association of radical superficial surgery and inelastic compressive dressings (utilized on a large scale in the management of VU in SUS units) and already established in literature ${ }^{(32-34)}$ may, thus, be seen as an important economic alternative to Brazilian public healthcare, with a potential for reproducibility in other emerging countries.

\section{OBJECTIVE}

To present an analysis of the costs of treatment of varicose ulcers using the association of two techniques - radical superficial varicose vein surgery and inelastic compressive dressings - and its comparison with the costs of managing ulcers merely with simple dressings.

\section{METHODS}

During the period between July 2009 and December 2009, 15 patients were selected at the outpatient's clinic of Vascular Surgery of the Hospital Geral de Carapicuiba, all presenting with advanced superficial CVI in the lower extremities, with skin alterations and active ulcer(s), that is, within the clinical criteria (C) of the Clinical, Etiological, Anatomical, and Pathophysiological Classification (CEAP) ${ }^{(35)}$ they were considered as class C6 of chronic venous disease.

All had CVI etiology and their ulcers were investigated by means of lower limb ultrasonography with color echo-Doppler and clinical history. The patients were also questioned as to the duration of the ulcers, management and care of the ulcers, presence or absence and frequency of recurrences.

It was decided to not create a control group accompanied by simple dressings, since it is known that these may not be considered treatment, per se, for venous ulcers, and this alternative could be classified as unethical. The study was approved by the Research Ethics Committee of the Hospital Geral de Carapicuíba; informed consent was given, and there were no conflicts of interest.

Excluded were patients with arterial insufficiency in lower extremities or of the deep venous system, patients 
submitted to prior surgical treatment of the lower limbs, and patients with infected ulcers.

The members of the study group had received prior clinical treatment with the use of elastic stockings and daily change of simple dressings with no definitive resolution of the ulcerous status, for periods that varied from 6 months to 17 years.

All participants presented with insufficiency of the greater saphenous vein and were submitted to radical surgery of the superficial venous system of the limbs with active ulcers, that is, saphenectomy aided by a stripper with ligation of the saphenofemoral joint, of its collateral branches and tributaries. Next, exeresis of collateral varicose veins was performed, besides ligation of previously marked incompetent perforating veins, following orientation of the ultrasound test and confirmed by palpation at the time of preoperative mapping.

Before hospital discharge, under medical supervision a compression dressing was placed. The patient was instructed to rest at home with the lower limbs elevated until the first outpatient visit, seven days later. At this visit, after removal of the stitches, a $9.14 \times 10.2 \mathrm{~cm}$ Unna boot was applied by a nurse, under medical orientation, and this dressing was to be changed weekly at follow-up clinical visits scheduled until the VU closed.

The following technique was adopted for the procedure:

- patient placed in the Trendelenburg position;

- removal of previous dressing and exposure of the lesion;

- cleaning of the ulcer with saline solution;

- measuring the lesion;

- application of the Unna boot;

- placement of crepe bandages and fixation with selfadhesive tape;

- patient removal from the gurney.

The ulcers were photographed and measured before and after the operation (Figure 1) and at the weekly follow-up visits to change the Unna boot. At these visits, the number of boots that each patient used was recorded, as well as the time from surgery to total remission of the ulcer (Figure 2), the presence of recurrences, complaints as to the use of the dressing, and whether its use was appropriate or not.

After the ulcers closed, the patients were instructed to daily use high-compression elastic stockings for six weeks, the time necessary to rehabilitate the traumatized lymphatic system. In cases of significant trophic lesions, such as fibrosis, hypodermitis, and severe pigmentation, the use of the stockings was indicated for 6 months in order to improve skin trophism, and its use was not necessary after this period. Reassessments were made at monthly

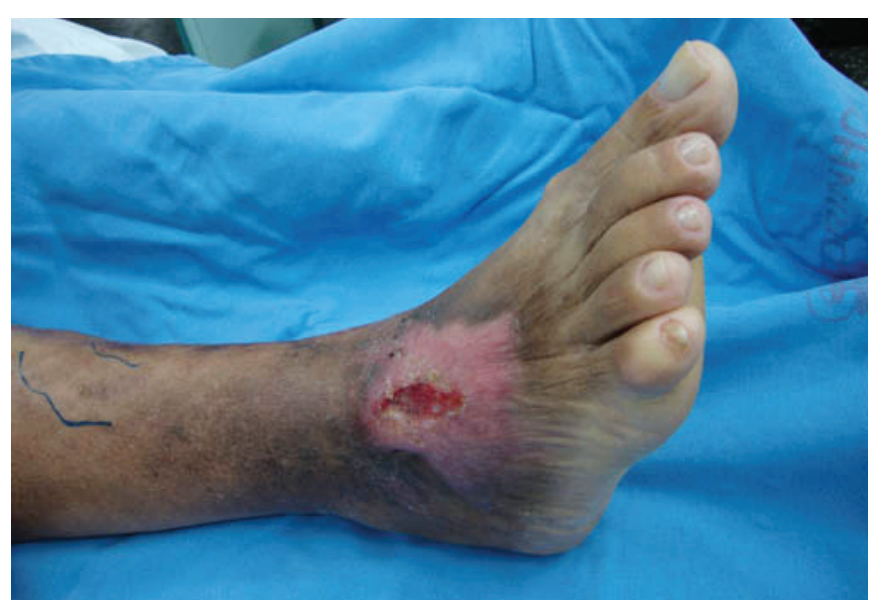

Figure 1. Preoperative ulcers

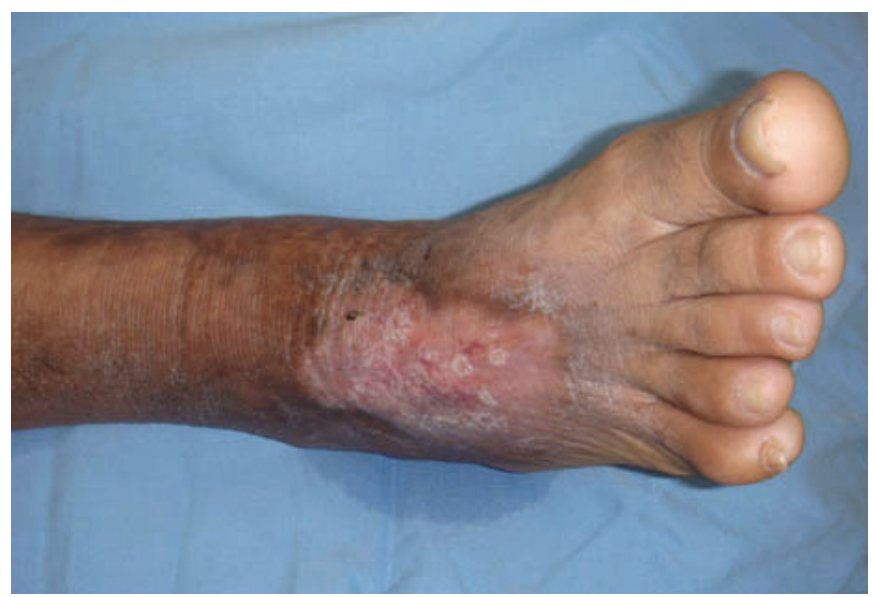

Figure 2. Healed ulcer in outpatient postoperative follow-up

follow-up visits, when the patient was also questioned as to the correct use (or not) of the elastic stockings.

The standard quantity of materials necessary for simple dressings and Unna boots was discriminated (Tables 1 and 2) and their values per day, week, and year were calculated so they could be compared to varicose ulcer combination treatment with radical surgery of the superficial venous system and the Unna boot, including values relative to

Table 1. Components and costs for application of simple wound dressings

\begin{tabular}{lllc}
\hline Material & $\begin{array}{c}\text { Quantity } \\
\text { (unit) }\end{array}$ & Unit Price (R\$) & $\begin{array}{c}\text { Price adjusted for } \\
\text { the quantity (R\$) }\end{array}$ \\
\hline Sterile gauzes $7.5 \times 7.5 \mathrm{~cm}$ & 20 & $0.23(10)$ & 0.46 \\
Rayon $7.5 \times 20 \mathrm{~cm}$ & 1 (unit) & $1.85(1 \mathrm{unit})$ & 1.85 \\
Elastic bandage $15 \times 180 \mathrm{~cm}$ & 1 (unit) & $0.39(1 \mathrm{unit})$ & 0.39 \\
Procedure glove & 1 (pair) & $0.3(1 \mathrm{pair})$ & 0.30 \\
Sterile glove & 1 (pair) & $1.32(1 \mathrm{pair})$ & 1.32 \\
Saline solution & $250(\mathrm{~mL})$ & $0.7(1 \mathrm{unit})$ & 0.70 \\
Paper sheet $0.8 \times 100 \mathrm{~m}$ & $2(\mathrm{~m})$ & $14(100 \mathrm{~m})$ & 0.28 \\
Dersani lotion $20 \mathrm{~mL}$ & $10(\mathrm{~mL})$ & $3.8(1 \mathrm{tube})$ & 1.90 \\
Self-adhesive tape $16 \times 50 \mathrm{~m}$ & $60(\mathrm{~cm})$ & $2.25(1 \mathrm{roll})$ & 0.03 \\
Nursing fees & $5(\mathrm{minutes})$ & $0.176(1 \mathrm{minute})$ & 0.88 \\
Total price $(\mathrm{R} \$)$ & & & 8.11 \\
\hline
\end{tabular}


Table 2. Components and costs related to application of an Unna boot

\begin{tabular}{lllc}
\hline Material & $\begin{array}{c}\text { Quantity } \\
\text { (unit) }\end{array}$ & Unit price (R\$) & $\begin{array}{c}\text { Price adjusted } \\
\text { for quantity (R\$) }\end{array}$ \\
\hline Unna boot & 1 (unit) & $25.00(1$ unit) & 25.00 \\
Elastic bandage $15 \times 180 \mathrm{~cm}$ & 1 (unit) & $0.39(1$ unit) & 0.39 \\
Procedure glove & 1 (pair) & $0.3(1$ pair) & 0.30 \\
Sterile glove & 1 (pair) & $1.32(1$ pair) & 1.32 \\
Saline solution & $250(\mathrm{~mL})$ & $0.7(1$ unit) & 0.70 \\
Paper sheet $0.8 \times 100 \mathrm{~m}$ & $2(\mathrm{~m})$ & $14(100 \mathrm{~m})$ & 0.28 \\
Self-adhesive tape $16 \times 50 \mathrm{~m}$ & $60(\mathrm{~cm})$ & $2.25(1 \mathrm{roll})$ & 0.03 \\
Nursing fees & $15(\mathrm{minutes})$ & $0.176(1 \mathrm{minute})$ & 2.64 \\
Total price $(\mathrm{R} \$)$ & & & 30.66 \\
\hline
\end{tabular}

hospitalization, medical visits, surgical procedure and anesthesia, outpatient follow-up, and elastic stockings.

All values were collected at the Invoicing Department of the Hospital Geral de Carapicuíba, in November, 2009.

To compare costs of the therapy proposed with the costs of daily simple dressings, the estimate of time during which the VU remained opened was used, since it is known that ulcer activity is frequently dynamic in the CVI patient.

The study was approved by the Research Ethics Committee, Hospital Geral de Carapicuíba and informed consent was obtained

\section{RESULTS}

Analyzing the data collected before and after surgery, the mean age of patients was 49.93 years (29 to 64 years), an age group within what would be expected for the Brazilian population, and there were four females and 11 males. The average total time of ulcer duration was 9.53 years (6 months to 17 years), representing the predominance of long-term ulcers.
The mean estimated time of an active ulcer was 5.08 years ( 0.4 to 9 years). When considering the percentages estimated for the time of an open ulcer, the value was $55.22 \%$ (40 to $80 \%$ ). Excluding ulcers with less than one year duration, the mean was $52.98 \%$ ( 40 to $69.23 \%$ ). The mean size of ulcers, considering the largest diameter, was $5.2 \mathrm{~cm}(1.8$ to $12.1 \mathrm{~cm})$ (Table 3$)$.

All patients analyzed were submitted to unilateral saphenectomy (greater saphenous) and removal of collateral varicose veins, besides ligation of incompetent perforating veins, with nolocal or systemic complications. They were discharged from the hospital on the first postoperative day, with compressive dressings and a return visit scheduled for one week later, when the first Unna boot was applied. On average, 4.13 Unna boots ( 2 to 7 boots) were used until closure of the ulcers. All of the 15 ulcers healed, and the mean time elapsed until ulcer healing was 5.07 weeks ( 3 to 9 weeks). There were no recurrences during the follow-up period, which, in average, lasted 7.67 months (4 to 11 months).

Patients were observed as to the correct use of the Unna boot (permanent use of the boot during the entire week), and it was noted that 13 patients fully complied to treatment $(86.67 \%)$. As to the correct use of the elastic stockings (daily use, from the time of awakening until removal at night to sleep, for 5 or more days during the week), only 3 patients $(20 \%)$ complied, albeit not completely (they used the stockings, but not during the entire day or for less than 5 days a week), and none of the patients did not comply with the treatment. Only one of those who partially complied with using the boot did so with the stocking, and the same thing happened with one of the patients who complied partially to the use of the elastic stocking, but completely to the Unna boot. There was no record of any allergic reaction that might impede the use of the Unna boot (Table 4).

Table 3. Characteristics of study patients

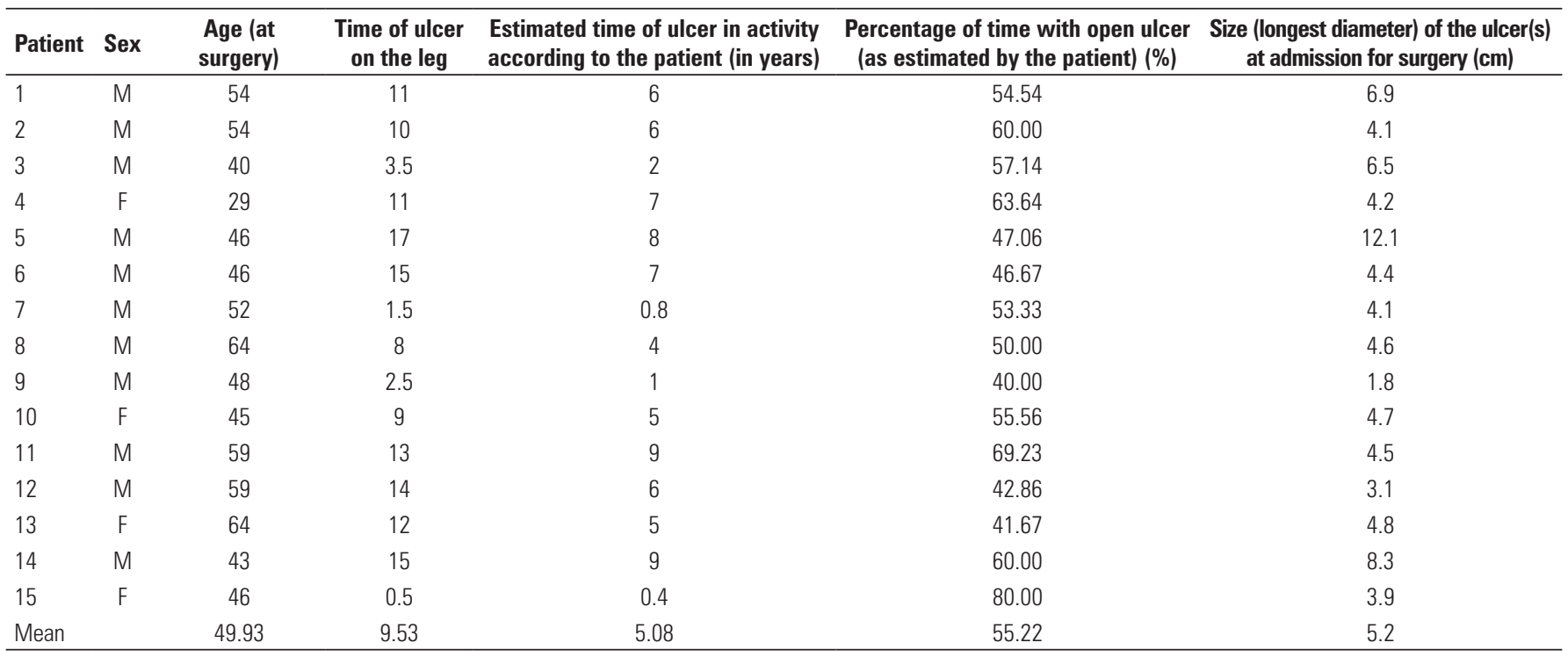

M: male; F: female. 
Table 4. Data referring to study patient follow-up

\begin{tabular}{|c|c|c|c|c|c|c|c|}
\hline Patient & Sex & $\begin{array}{c}\text { Number of Unna } \\
\text { boots used }\end{array}$ & $\begin{array}{l}\text { Time for closure of ulcer(s) } \\
\text { in weeks after surgery }\end{array}$ & $\begin{array}{c}\text { Correct use of boot } \\
\text { (scheduled weekly changes) }\end{array}$ & $\begin{array}{l}\text { Elastic stockings } \\
\text { after ulcer remission }\end{array}$ & $\begin{array}{c}\text { Follow-up } \\
\text { time (months) }\end{array}$ & $\begin{array}{l}\text { Occurrence of relapse } \\
\text { after combined treatment }\end{array}$ \\
\hline 1 & $\mathrm{M}$ & 3 & 4 & Yes & Yes & 9 & No \\
\hline 2 & $\mathrm{M}$ & 3 & 4 & Yes & Yes & 9 & No \\
\hline 3 & $\mathrm{M}$ & 6 & 7 & Yes & Yes & 9 & No \\
\hline 4 & $\mathrm{~F}$ & 7 & 9 & Partial & Partial & 10 & No \\
\hline 5 & $\mathrm{M}$ & 5 & 6 & Yes & Yes & 10 & No \\
\hline 6 & $\mathrm{M}$ & 5 & 6 & Yes & Yes & 10 & No \\
\hline 7 & $\mathrm{M}$ & 6 & 7 & No & Partial & 8 & No \\
\hline 8 & $\mathrm{M}$ & 6 & 7 & Yes & Yes & 10 & No \\
\hline 9 & $\mathrm{M}$ & 2 & 3 & Partial & Yes & 5 & No \\
\hline 10 & $\mathrm{~F}$ & 3 & 4 & Yes & Yes & 11 & No \\
\hline 11 & $\mathrm{M}$ & 3 & 4 & Yes & Yes & 6 & No \\
\hline 12 & $\mathrm{M}$ & 3 & 4 & Yes & Yes & 4 & No \\
\hline 13 & $\mathrm{~F}$ & 3 & 4 & Yes & Partial & 5 & No \\
\hline 14 & $\mathrm{M}$ & 4 & 5 & Yes & Yes & 5 & No \\
\hline 15 & $\mathrm{~F}$ & 3 & 4 & Yes & Yes & 4 & No \\
\hline Mean & & 4.13 & 5.07 & & & 7.666 & \\
\hline
\end{tabular}

M: male; F: female.

After summing up the values of the components of using a simple dressing and those of using an Unna boot, an accentuated difference was noted, with the figures already standardized by the periods of one day, one week, and one year. While the use of the simple dressing on an open ulcer during one year cost the public authoritied $\mathrm{R} \$ 56.75 /$ week, or $\mathrm{R} \$ 8.11 /$ daily dressing (or, approximately, US $\$ 35.75$ and US\$5.11, respectively), the use of the Unna boot cost $\mathrm{R} \$ 30.66 /$ week (or, approximately, US\$19.31), representing a 45.98\% saving (Table 5).

In order to compare the costs of follow-up, the mean values of hospital visits, outpatient clinic appointments, and number of Unna boots used were applied to reach the total expenditure in therapy

Table 5. Comparisons between procedures

\begin{tabular}{lccc}
\hline Dressing/Procedure & $\begin{array}{c}\text { Price adjusted } \\
\text { by day (R\$) }\end{array}$ & $\begin{array}{c}\text { Price adjusted } \\
\text { by week (R\$) }\end{array}$ & $\begin{array}{c}\text { Price adjusted } \\
\text { by year (R\$) }\end{array}$ \\
\hline Daily dressing & 8.11 & 56.75 & $2,959.05$ \\
Unna's boot & 4.38 & 30.66 & $1,598.54$ \\
Difference (R\$) & 3.73 & 26.09 & $1,360.51$ \\
Difference (\%) & -45.98 & & \\
\hline
\end{tabular}

combined with surgery and Unna boot (Table 6). The value of performing the daily simple dressing over the period of one year is 3.58 times greater than the total cost of therapy with surgery and the Unna boot ( $\mathrm{R} \$ 2,959.05$ versus $\mathrm{R} \$ 826.53$ or, approximately, US $\$ 1,864.55$ versus US\$520.82), having already added to the costs of the latter the values spent for outpatient visits at 1,3 , and 6 months after ulcer closure, and of a pair of high compression elastic stockings - which are not routinely furnished by the SUS. The costs of the dressings and follow-up are discriminated in Table 7.

Table 7. Comparison of daily, weekly, and annual cost for daily simple dressings, weekly change of the Unna boot, and the cost of combined therapy using surgery, Unna's boot, and elastic stockings

\begin{tabular}{lccc}
\hline Dressing/procedure & $\begin{array}{c}\text { Price adjusted } \\
\text { per day (R\$) }\end{array}$ & $\begin{array}{c}\text { Price adjusted } \\
\text { per week (R\$) }\end{array}$ & $\begin{array}{c}\text { Price adjusted } \\
\text { per year (R\$) }\end{array}$ \\
\hline Daily dressing & 8.11 & 56.75 & $2,959.05$ \\
Unna's boot & 4.38 & 30.66 & $1,598.53$ \\
$\begin{array}{l}\text { Surgery + boot }+ \\
\text { return visits + stockings }\end{array}$ & 2.27 & 15.89 & 826.53 \\
$\begin{array}{l}\text { Surgery + boot }+ \\
\text { return visits }\end{array}$ & 2.11 & 14.80 & 771.53 \\
\hline
\end{tabular}

Table 6. Total cost of combined therapy: saphenectomy magna + Unna's boot + accompaniment

\begin{tabular}{|c|c|c|c|c|}
\hline Clinical visit & Procedure & Quantity (mean) & Unit price $(R \$)$ & $\begin{array}{c}\text { Price adjusted } \\
\text { for quantity ( } \mathrm{R} \$ \text { ) }\end{array}$ \\
\hline Outpatient - SUS & & 8.07 & 10.00 (1 unit) & 80.70 \\
\hline \multirow[t]{3}{*}{ Visit to the ward (clinical evolution) - SUS } & & 2 & 40.38 (1 unit) & 80.76 \\
\hline & Surgical treatment of varices (unilateral) - SUS & 1 & 483.37 (1 unit) & 483.37 \\
\hline & High compression elastic stockings - Not routinely furnished by SUS & 1 & 55.00 (1 pair) & 55.00 \\
\hline
\end{tabular}


It is known that varicose ulcers do not remain active continually during their history, nevertheless, there are no studies estimating the quantity of time during which they remain open. Therefore, the mean percentage of patients of the present study of $55.22 \%$ of the total duration of the ulcer of the time it was open and active was used to reach figures for comparison, which would be the same: $\mathrm{R} \$ 826.53$ in one year for combined therapy and $\mathrm{R} \$ 1,634.29 /$ year (or, approximately, US\$1,029.79) for the daily simple dressing.

In this way, the annual cost of simple dressings is 1.98 times greater, which means that, when combined therapy is used, there is an almost $50 \%$ $(49.43 \%)$ economy, even when not including in the total cost of the simple dressings the expenses with hospitalizations and follow-up visits, which certainly would occur more frequently, besides the elastic stockings (Table 8).

Table 8. Comparison of costs considering the ulcer open during $55.223 \%$ of the time of its history

\begin{tabular}{lccc}
\hline Dressing/procedure & $\begin{array}{c}\text { Price adjusted } \\
\text { by day (R\$) }\end{array}$ & $\begin{array}{c}\text { Price adjusted } \\
\text { by week (R\$) }\end{array}$ & $\begin{array}{c}\text { Price adjusted } \\
\text { by year (R\$) }\end{array}$ \\
\hline Daily dressings & 4.48 & 31.34 & $1,634.08$ \\
$\begin{array}{l}\text { Surgery + boot + } \\
\text { returning visits + stockings }\end{array}$ & 2.27 & 15.89 & 826.53 \\
Difference (R\$) & 2.21 & 15.44 & 807.54 \\
Difference (\%) & -49.27 & & \\
\hline
\end{tabular}

Among our patients, the mean annual cost of simple dressings performed during the time of existence of the varicose ulcer, considering only the estimated time of the individual open ulcer and not the total time of history, nor the mean time estimated of the open ulcer. The average costs were $\mathrm{R} \$ 1,620.95$ or, approximately, US\$1,021.39 ( $\mathrm{R} \$ 1,183.62$ to $2,367.24$ or, approximately, US $\$ 745.82$ to $1,491.64$ ), a figure $57.29 \%$ greater than the mean value of combined therapy with surgery and the Unna boot, of $\mathrm{R} \$ 717.85$ or, approximately, US\$452.33 (R $\$ 630.44$ to 843.73 or, approximately, US $\$ 397.25$ to 531.65$)$. Even the lower value of simple dressings per year ( $\mathrm{R} \$ 1,183.62$ or, approximately, US\$745.82) was greater than the highest value of combined therapy for one year ( $\mathrm{R} \$ 843.73$ or, approximately, US\$531.65) (Table 9).

The total mean cost expended in caring for ulcers with simple daily dressings over their entire history had an estimated mean of $\mathrm{R} \$ 28,209.66$ or, approximately, US\$17,775.46 ( $\mathrm{R} \$ 1,479.53$ to $50,303.93$ or, approximately, US\$932.28 to $31,697.49$ ), but when considering the mean time of the open ulcer as $55.22 \%$ of the total value, the mean value was $\mathrm{R} \$ 15,578.22$ or, approximately, US\$9,816.14 ( $\mathrm{R} \$ 817.04$ to $27,779.34$ or, approximately, US\$514.83 to $17,504.31)$. When taking into consideration the total cost as per the individual percentage of time of an active ulcer, the mean was $\mathrm{R} \$ 15,031.96$ or, approximately, US $\$ 9,471.93$ ( $\mathrm{R} \$ 1,183.62$ to $26,631.49$ or, approximately, US\$745.82 to $1,6781.02$ ) (Table 10).

Table 9. Data on the time of ulcer (total and active) and values spent with simple dressings per year compared to the value spent with therapy combined with surgery and Unna's boot

\begin{tabular}{|c|c|c|c|c|c|}
\hline Patient & $\begin{array}{c}\text { Time of ulcer } \\
\text { on leg }\end{array}$ & $\begin{array}{l}\text { Estimated time of ulcer } \\
\text { in activity as per the } \\
\text { patient (in years) }\end{array}$ & $\begin{array}{l}\text { Total estimated cost of dressings } \\
\text { considering } 55.223 \% \text { of the time } \\
\text { with an active ulcer (R\$) }\end{array}$ & $\begin{array}{l}\text { Annual cost according to the } \\
\text { individual percentage of time of } \\
\text { active ulcer ( } R \$ \text { ) }\end{array}$ & $\begin{array}{l}\text { Absolute cost of therapy } \\
\text { combined with surgery and } \\
\text { Unna's boot ( } R \$)\end{array}$ \\
\hline 1 & 11.0 & 6.0 & $17,974.87$ & $1,614.02$ & 671.10 \\
\hline 2 & 10.0 & 6.0 & $16,340.79$ & $1,775.43$ & 671.10 \\
\hline 3 & 3.5 & 2.0 & $5,719.27$ & $1,690.89$ & 793.07 \\
\hline 4 & 11.0 & 7.0 & $17,974.87$ & $1,883.03$ & 843.73 \\
\hline 5 & 17.0 & 8.0 & $27,779.34$ & $1,392.47$ & 752.41 \\
\hline 6 & 15.0 & 7.0 & $24,511.18$ & $1,380.89$ & 752.41 \\
\hline 7 & 1.5 & 0.8 & $2,451.12$ & $1,578.15$ & 793.07 \\
\hline 8 & 8.0 & 4.0 & $13,072.63$ & $1,479.53$ & 793.07 \\
\hline 9 & 2.5 & 1.0 & $4,085.20$ & $1,183.62$ & 630.44 \\
\hline 10 & 9.0 & 5.0 & $14,706.71$ & $1,643.92$ & 671.10 \\
\hline 11 & 13.0 & 9.0 & $21,243.03$ & $2,048.58$ & 671.10 \\
\hline 12 & 14.0 & 6.0 & $22,877.10$ & $1,268.17$ & 671.10 \\
\hline 13 & 12.0 & 5.0 & $19,608.95$ & $1,232.94$ & 671.10 \\
\hline 14 & 15.0 & 9.0 & $24,511.18$ & $1,775.43$ & 711.76 \\
\hline 15 & 0.5 & 0.4 & 817.04 & $2,367.24$ & 671.10 \\
\hline Mean & 9.53 & 5.080 & $15,578.22$ & $1,620.95$ & 717.84 \\
\hline
\end{tabular}


Table 10. Estimated cost for management of varicose ulcer continually along its history. Estimated cost considering the mean time of open ulcer between the group studied and considering the individual percentage of time of open ulcer

\begin{tabular}{lcccc}
\hline Patient & $\begin{array}{c}\text { Percentage of time with open ulcer } \\
\text { (as estimated by the patient) }(\%)\end{array}$ & $\begin{array}{c}\text { Total absolute cost if ulcer is } \\
\text { considered permanently open (R\$) }\end{array}$ & $\begin{array}{c}\text { Cost considering 55.223\% of the } \\
\text { time with active ulcer (R\$) }\end{array}$ & $\begin{array}{c}\text { Total cost according to individual } \\
\text { percentage of active ulcer time (R\$) }\end{array}$ \\
\hline 1 & 54.54 & $32,549.60$ & $17,974.87$ & $17,754.18$ \\
2 & 60.00 & $29,590.55$ & $16,340.79$ & $17,754.33$ \\
3 & 57.14 & $10,356.69$ & $5,719.28$ & $5,918.11$ \\
4 & 63.64 & $32,549.60$ & $17,974.87$ & $20,713.38$ \\
5 & 47.06 & $50,303.93$ & $27,779.34$ & $23,672.03$ \\
6 & 46.67 & $44,385.82$ & $24,511.18$ & $20,713.38$ \\
7 & 53.33 & $4,438.58$ & $2,451.12$ & $2,367.23$ \\
8 & 50.00 & $23,672.44$ & $13,072.63$ & $11,836.22$ \\
9 & 40.00 & $7,397.64$ & $4,085.20$ & $2,959.05$ \\
10 & 55.56 & $26,631.49$ & $14,706.71$ & $14,795.27$ \\
11 & 69.23 & $38,467.71$ & $21,243.03$ & $26,631.49$ \\
12 & 42.86 & $41,426.77$ & $22,877.10$ & $17,754.33$ \\
13 & 41.67 & 35.508 .66 & $19,608.95$ & $14,795.27$ \\
14 & 60.00 & $44,385.82$ & $24,511.18$ & $26,631.49$ \\
15 & 80.00 & $1,479.53$ & 817.04 & $1,183.62$ \\
Mean & 55.22 & $28,209.66$ & $15,578.22$ & $15,031.96$ \\
\hline
\end{tabular}

\section{DISCUSSION}

The cost-effectiveness analysis in managing VU is nothing new in medical literature, since there are publications comparing different types of dressings and comparing surgery to compressive dressings ${ }^{(36-39)}$, with results that suggest that the best treatments are, in fact, surgery of the superficial venous system (when well indicated) and compressive dressings, with the advantages for the former since it decreases the recurrence rate ${ }^{(33,37)}$, as it definitively treats the causative factor, despite presenting a surgical risk. Nonetheless, in literature, we found no study that proposes an association between surgery and the use of the compressive dressing, and compares its costs with those of the daily simple dressing, amply used by SUS services in VU followup. This is probably due to the fact that in countries where the most of the studies were conducted, simple dressings are not used since they are not therapeutic. In Brazil, because they are simpler, these cause the false impression that they are also less expensive, and are utilized all over the country.

It is noteworthy that surgery and compression generate better results than simple dressings, but there is a lack of comparative studies as to their costs. For this reason, we proposed in this study, the analysis of expenses related to the association of using Unna's boot and surgery and further, the comparison with the costs of using simple dressings in an effort to exemplify, by means of numbers, that the active search for VU cases and the timely initiative in resolving them should be more economical for public health than accompaniment with daily changing of simple dressings. It is important to point out that these may not be considered therapeutic, and therefore, should not be compared as to efficacy with any other mode of treatment.

Therefore, supposing that the prevalence of active VUs in Brazil is similar to that of Europe, in other words, $1 \%$, we are probably underestimating the figures and even so, there are most likely almost 2 million Brazilians with this disease, considering the present Brazilian population, according to the Instituto Brasileiro de Geografia e Estatística (IBGE) [Brazilian Institute of Geography and Statistics]. Knowing that approximately $53 \%{ }^{(36)}$ of VUs are caused exclusively by insufficiency of the superficial venous system, we reach an approximate number of 1.06 million cases of $\mathrm{VU}$ that would benefit from surgery of their venous system in the country. Of these, it is known that $40 \%$ remain open for one year or more ${ }^{(27,28)}$, the equivalent to 424,000 ulcers exclusively caused by the superficial venous system that remain open for a period of over one year.

If these 424,000 patients are accompanied with daily dressings, $\mathrm{R} \$ 692,849.49 /$ year will be spent, or approximately, US $\$ 436,578.12$, already taking into consideration that these VUs remain, in fact, open and require dressings during $55.22 \%$ of the time, as was observed in our survey.

With the use of combined therapy using surgery of the superficial venous system and the Unna boot dressing, a practical and economical solution has been found for managing the VU patient. While a patient clinically assisted, with daily changing of simple dressings represents an annual cost of approximately $\mathrm{R} \$ 1,650.00 / \mathrm{year}$, or approximately, US $\$ 1,039.69$, a patient who received the use of the combined therapy proposed has an annual cost of less than $\mathrm{R} \$ 900.00$ or, approximately, US\$567.10. 
Other benefits include the need for ongoing followup at the healthcare service, allowing early visualization of recurrence and complications, protection of the wound against possible contamination, and the possibility of using only one dressing even in the case of multiple VUs or ulcers of large proportions, which is impossible in the case of simple dressings. Additionally, there are positive factors already confirmed in literature, such as a lower rate of relapses ${ }^{(33)}$, decreased healing time ${ }^{(37)}$, quicker return to work, and the possibility of using compression even with an open ulcer.

It is noteworthy that with early diagnosis and treatment of patients that participated in the study, we were able to avoid large expenditures, since some of the subjects had long-standing VUs with absolute individual expenditures, considering simple dressings alone, of up to $\mathrm{R} \$ 28,000.00$ or, approximately, US $\$ 17,643.35$. In this way, the attempt to extend these values to the Brazilian healthcare system is important.

Comparatively, if the same patients are treated with combined therapy, composed by radical varicose vein surgery and the Unna boot, expenses reach $\mathrm{R} \$ 350,450,840.00 /$ year or, approximately, US $\$ 220,852,98.00$, generating a surprising and significant economy of $\mathrm{R} \$ 342,398,656.00 /$ year or, approximately, US $\$ 215,752,140.00$ for the SUS merely during the first year. In the following years, these savings should be amplified, since there would be no need for renewed costs with surgery, and relapses, once this disorder is corrected, are significantly less frequent.

The values of both therapies were calculated for cases in which only one limb was affected, and therefore, the savings might be even greater when including bilateral cases of VUs. One should also remember the fact that in calculating costs with a VU clinically accompanied with simple dressings, expenditures with possible hospitalizations, outpatient appointments, and elastic stockings were not included, differing from the calculation of expenses for combined therapy, in which these items were incorporated. And without including the costs of elastic stockings in combined therapy, since they are not routinely provided by the SUS, the savings jump to $\mathrm{R} \$ 365,718,656,00 /$ year or, approximately, US\$230,446,660.00/year, and this merely in the first year.

\section{CONCLUSION}

The routine application of Unna's boot associated with radical varicose vein surgery promoted significant savings for the Brazilian United Healthcare System (SUS) in the group evaluated and also diminished the healing time of ulcers, as was expected.

This choice may be considered a true alternative for obtaining the same results in the rest of the country and in other emerging countries, although larger scale studies are still necessary.

\section{ACKNOWLEDGEMENTS}

We thank LM Farma, which kindly provided the Unna $\left(\right.$ Curatec $^{\circledR}$ ) boots for conducting this study.

\section{REFERENCES}

1. Castro e Silva M, Cabral ALS, Barros Jr N, Castro AA, Santos MERC. Diagnóstico e tratamento da doença venosa crônica. J Vasc Br. 2005;4(Supl. 2):S185-94.

2. Bergan JJ, Schmid-Schönbein GW, Smith PD, Nicolaides AN, Boisseau MR, Eklof B. Chronic venous disease. N Engl J Med. 2006;355(5):488-98.

3. Heit JA, Rooke TW, Silverstein MD, Mohr DN, Lohse CM, Petterson TM, et al. Trends in the incidence of venous stasis syndrome and venous ulcer: a 25-year population-based study. J Vasc Surg. 2001;33(5):1022-7.

4. Callam MJ. Epidemiology of varicose veins. Br J Surg. 1994;81 (2):167-73.

5. Margolis DJ, Knauss J, Bilker W. Medical conditions associated with venous leg ulcers. Br J Dermatol. 2004;150(2):267-73.

6. Ruckley CV, Evans CJ, Allan PL, Lee AJ, Fowkes FG. Chronic venous insufficiency: clinical and duplex correlations. The Edinburgh vein study of venous disorders in the general population. J Vasc Surg. 2002;36(3):520-5.

7. Graham ID, Harrison MB, Nelson EA, Lorimer K, Fisher A. Prevalence of lowerlimb ulceration: a systematic review of prevalence studies. Adv Skin Wound Care. 2003;16(6):305-16.

8. Maffei FH, Magaldi C, Pinho SZ, Lastoria S, Pinho W, Yoshida WB, et al. Varicose veins and chronic venous insufficiency in Brazil: prevalence among 1,755 inhabitants of a country town. Int J Epidemiol. 1986;15(2):210-7.

9. Nelzén 0. Leg ulcers: economic aspects. Phlebology. 2000;15:110-4.

10. Ruckley CV. Socioeconomic impact of chronic venous insufficiency and leg ulcers. Angiology. 1997;48(1):67-9.

11. Simon DA, Freak L, Kinsella A, Walsh J, Lane C, Groarke L, et al. Community leg ulcer clinics: a comprehensive study in two health authorities. BMJ. 1996;312(7047):1648-51.

12. Cherry GW. New compression bandage for treatment of venous leg ulcers. In: Kerstein MD, editor. New trends in wound healing for vascular surgeons: highlights of a symposium. Los Angeles, EUA: Excerpta Médica; 1990. p. 25-9.

13. National Prescribing Centre. Modern wound dressings: the absence of evidence. In: National Prescribing Centre. MeReC Extra Issue No. 31. NHS: Liverpool, 2008. p. 2.

14. Sultan MJ, McCollum C. Don't waste money when dressing leg ulcers. Br J Surg. 2009;96(10):1099-100.

15. Ragnarson Tennvall G, Hjelmgren J. Annual costs of treatment for venous leg ulcers in Sweden and the United Kingdom. Wound Repair Regen. 2005;13(1):13-8.

16. Silva Mde C. Chronic venous insufficiency of the lower limbs and its socioeconomic significance. Int Angiol. 1991;10(3):152-7.

17. Dados do DATASUS relativos aos years de 2000 e 2009 [Internet]. Brasília: Ministério da Saúde - Departamento de Informática do SUS (DATASUS); 2008-2010. [citado 2010 Mar 12]. Disponível em: http://www2.datasus.gov. br/DATASUS/index.php.

18. Callam MJ, Harper DR, Dale JJ, Ruckley CV. Chronic ulcer of the leg: clinical history. Br Med J (Clin Res Ed). 1987;294(6584):1389-91.

19. Bergqvist D, Lindholm C, Nelzén 0 . Chronic leg ulcers: the impact of venous disease. J Vasc Surg. 1999;29(4):752-5.

20. Callam MJ, Ruckley CV, Harper DR, Dale JJ. Chronic ulceration of the leg: extent of the problem and provision of care. Br Med J (Clin Res Ed). 1985;290(6485):1855-6.

21. de Araujo T, Valencia IC, Federman DG, Kirsner RS. Managing the patient with venous ulcers. Ann Intern Med. 2003;138(4):326-34. 
22. Baptista CM, Castilho V. Cost survey of procedure with Unna boot in patients with venous ulcer. Rev Latinoam Enferm. 2006;14(6):944-9.

23. Collier M. Tissue viability. Leg ulceration: a review of causes and treatment. Nurs Stand. 1996;10(31):49-51.

24. Nelzén 0, Bergqvist D, Lindhagen A. Long-term prognosis for patients with chronic leg ulcers: a prospective cohort study. Eur J Vasc Endovasc Surg. 1997;13(5):500-8.

25. Moffat CJ, Franks PJ, Oldroyd M, Bosanquet N, Brown P, Greenhalgh $\mathrm{RM}$, et al. Community clinics for leg ulcers and impact on healing. BMJ. 1992;305(6866):1389-92.

26. Harrison MB, Graham ID, Friedberg E, Lorimer K, Vandevelde-Coke S. Regional planning study: assessing the population with leg and foot ulcers. Can Nurse. 2001;97(2):18-23.

27. Briggs M, Flemming K. Living with leg ulceration: a synthesis of qualitative research. J Adv Nurs. 2007;59(4):319-28.

28. Nelzén 0, Bergqvist D, Lindhagen A. Venous and non venous leg ulcers: clinical history and appearance in a population study. Br J Surg. 1994;81 (2):182-7.

29. Briggs M, Closs SJ. The prevalence of leg ulceration; a review of the literature. Eur Wound Manag Assoc J. 2003;3(2):14-20.

30. Jull A, Walker N, Parag V, Molan P, Rodgers A; Honey as Adjuvant Leg Ulcer Therapy trial collaborators. Randomized clinical trial of honey-impregnated dressings for venous leg ulcers. Br J Surg. 2008;95(2):175-82.

31. Dumville JC, Worthy G, Bland JM, Cullum N, Dowson C, Iglesias C, Mitchell JL, Nelson EA, Soares MO, Torgerson DJ; VenUS II team. Larval therapy for leg ulcers (VenUS II): randomized controlled trial. BMJ. 2009;338:b773.
32. Howard DP, Howard A, Kothari A, Wales L, Guest M, Davies AH. The role of superficial venous surgery in the management of venous ulcers: a systematic review. Eur J Vasc Endovasc Surg. 2008;36(4):458-65.

33. Gohel MS, Barwell JR, Taylor M, et al. Long term results of compression therapy alone versus compression plus surgery in chronic venous ulceration (ESCHAR study): randomised controlled trial. BMJ. 2007;335(7610):83.

34. O'Meara S, Cullum NA, Nelson EA. Compression for venous leg ulcers. Cochrane Database Syst Rev. 2009;(1)CD000265.

35. Kistner RL, Eklof B, Masuda EM. Forum Diagnosis of chronic venous disease of the lower extremities: the "CEAP" classification. Mayo Clin Proc. 1996;71(4):338-45.

36. Shami SK, Sarin S, Cheatle TR, Scurr JH, Smith PD. Venous ulcers and the superficial venous system. J Vasc Surg. 1993;17(3):487-90.

37. Zamboni P, Cisno C, Marchetti F, Mazza P, Fogato L, Caradina S, et al. Minimally invasive surgical management of primary venous ulcers vs. compression treatment: a randomised clinical trial. Eur J Vasc Endovasc Surg. 2002;25(4):313-8.

38. Ohlsson P, Larsson K, Lindholm C, Möller M. A cost-effectiveness study of leg ulcer treatment in primary care. Comparison of saline-gauze and hydrocolloid treatment in a prospective, randomized study. Scand J Health Care. 1994;12(4):295-9.

39. Kerstein MD, Gemmen E, van Rijswick L, Lyder CH, Phillips T, Xakellis G, et al. Cost and cost effectiveness of venous and pressure ulcer protocols of care. Dis Manage Health Outcomes. 2001;9(11):651-63. 